\title{
Electrophoretic detection of interspecific hybrids in Parnassius (Lepidoptera Papilionidae)
}

\author{
H. DESCIMON * and H. GEIGER ** \\ * Université de Provence, Laboratoire de Systématique Evolutive, \\ 3, place Victor-Hugo, 13331 Marseille Cedex, France \\ ** Universität Bern, Zoologisches Institut, Baltzerstrasse 3, \\ CH 3012 Bern, Suisse
}

\begin{abstract}
Summary
Electrophoretic techniques confirm that the papilionid butterflies Parnassius apollo and $P$. phobus, two sympatric taxa usually considered as distinct species, display hybridization phenomena in limited areas of their range. Morphological criteria provided only presumptions and poor genetical indications. Moreover, it is possible to demonstrate that some gene flow is possible between the two species. The implications for the "semispecies" concept and interspecific gene exchange are discussed.
\end{abstract}

Key words : interspecific hybrid, Parnassius apollo, Parnassius phœbus, gene flow, electrophoresis.

\section{Résumé}

Détection électrophorétique d'hybrides interspécifiques dans le genre Parnassius (Lépidoptères Papilionidés)

Les techniques électrophorétiques confirment que les papillons Parnassius apollo et $P$. phoebus, deux taxa de la famille des Papilionidés habituellement considérés comme deux espèces sympatrides bien distinctes, montrent des phénomènes d'hybridation dans des parties limitées de leurs aires. Les critères morphologiques ne fournissaient que des présomptions inutilisables au niveau génétique. De plus, il est ainsi possible de démontrer qu'un certain flux génique est possible entre les deux espèces. Les implications pour le concept de "semi-espèce " et les échanges géniques interspécifiques sont discutées.

Mots clés : hybride interspécifique, Parnassius apollo, Parnassius phœbus, flux génique, électrophorèse.

\section{Introduction}

Reports on field collected interspecific hybrids are numerous in insects. In most cases, these observations have been based upon an analysis of morphological characters. Such hybrids are especially easy to detect in butterflies by visual examination of the 
wing pattern. One example of hybridization between butterfly species concerns Parnassius apollo $\mathrm{L}$. and $P$. phobus Fabr., two taxa that are generally considered by entomologists as specifically distinct. The former is widespread in the European mountains, but also occurs at lower altitudes in Scandinavia, whereas the second is limited to the higher altitudes of the Alps, where broad zones of sympatry with $P$. apollo exist. Supposed hybrids between these two species have been reported several times (EISNER, 1966). However, only morphological characters were considered and although several clearcut differences are available for diagnosis, some ambiguity remains. A supposed hybrid might be merely a pure individual of one species which presents by chance characters convergent towards those of the other one ; moreover, its generation rank ( $F 1$ or further) is difficult to ascertain. Comparable difficulties have been met with in hybridization studies carried out in other zoological groups (NeFF \& SMITH, 1979 ; LAMB \& Avise, 1987).

Such natural hybridization events are of considerable interest, since they provide evidence for the occurrence of interspecific gene exchange or introgression (ANDERSON, 1949). Such a phenomenon is well documented in the case of hybrid belts between closely related, parapatric taxa (BARTON \& HewITT 1983), but is poorly known for sympatric species (WoodRUFF, 1973). In animals, it seems to be a rule that the nuclear gene pool is protected from contamination by genes of other species by very strong mechanisms (MAYR, 1963). Traditionally, various explanations have been proposed for this fact ; the first and most obvious one is the sterility of $F 1$-hybrids, or of further generations if this sterility is only partial, and the physiological dysharmonies between the genes of the hybrids (named "hybrid breakdown" for Lepidoptera by OLIVER, 1979). However, observations on mitochondrial DNA suggest more genetic exchange between animal species than formerly thought (PowELL, 1983).

Natural hybridization between $P$. apollo and $P$. phobus has been observed and studied in the Southern Alps for many years by one of us (H.D.). However, owing to the limitations inherent to morphological criteria, enzyme electrophoresis was used in an attempt to establish more precisely the status of presumed hybrids.

\section{Materials and methods}

Table 1 gives a list of the sampling sites for both taxa and the number of animals investigated. The methods used for electrophoresis and the enzymes scored have been described in a previous paper (NAPolitano et al., 1988). Designation of alleles was made on the basis of relative mobility of the electromorph with 100 representing the most frequent electromorph in $P$. apollo.

Presumed hybrids have been collected for electrophoresis in two localities in August 1983 and 1984. The first of these is situated in the neighbourhood of the Col du Galibier, North of Briançon (Hautes-Alpes, France), on a steep S.-W. exposed slope, traversed by small rills, at an altitude of $2200-2400 \mathrm{~m}$. In this area, the habitats of the two parental species overlap to an extent which is scarcely encountered in other localities; the climate is such that the lag usually observed between the hatching times of both species is greatly reduced or non-existent. The population of $P$. apollo from this locality is situated at the upper limit of the altitudinal range of the species. The second locality lies in the Boréon valley, in the Mercantour massif, close to Saint- 
Martin Vésubie, Alpes Maritimes, France. Although a little lower (1 900-2 $100 \mathrm{~m}$ ) than the first locality, its features recall strongly those of this latter, in particular by the intrication of flight places. The peculiar, very stormy, climate of Mercantour influences the flight periods of the Parnassius species which, for $P$. phobus, is much later than in the neighbouring regions of the Alpes de Haute Provence. Apparently isolated geographically from the other populations of $P$. phobus, the butterflies from Mercantour have been placed in a separate subspecies ( $P$. phoebus gazeli Praviel) which recent studies indicate is morphologically, ecologically and genetically quite distinct (DESCIMON et al., in preparation).

TABLE 1

Population samples and number of animals investigated (all the localities are located in French Southern Alps)

\begin{tabular}{|c|c|c|c|c|c|}
\hline Species & Origin & Number & Species & Origin & Number \\
\hline P. apollo & Boréon 1 & 14 & P. phoebus & Champsaur & 20 \\
\hline P. apollo & Galibier 1 & 11 & P. phobus & Crévoux & 8 \\
\hline P. apollo & Galibier 2 & 9 & P. phobus & Fontgillarde & 20 \\
\hline \multirow[t]{2}{*}{ P. apollo } & Les Ayes & 10 & P. phobus & Galibier 1 & 10 \\
\hline & & & P. phoebus & Galibier 2 & 8 \\
\hline P. apollo & Rosans & 13 & P. phobbus & Jausiers & 21 \\
\hline P. phabus & Abriès & 12 & P. phabus & Larche & 13 \\
\hline P. phobus & Boréon 2 & 16 & P. phobus & Les Ayes & 14 \\
\hline P. phobus & Ceillac & 16 & P. phoebus & Maurin & 7 \\
\hline P. phabus & Cervières & 12 & & & \\
\hline
\end{tabular}

In the Galibier area, hybrids have been regularly observed between 1970 and 1986 . Their frequency has been roughly estimated to vary between 1 and $10 \%$ of the total Parnassius population in different years. In the Boréon region hybridization has been investigated for fewer years, but hybrids have been also observed regularly and perhaps with a higher frequency. A female preserved in the collection of the Laboratory of Entomology of the Museum National d'Histoire Naturelle in Paris (P. Capdeville leg.) indicates that hybridization occurred already in 1971.

\section{Results}

At 20 of the 24 loci scored, $P$. apollo and $P$. phobus had the same alleles in common. The frequencies of these alleles were different at certain loci (especially GOT-1 and GPT) and also varied between individual population samples of one species ( $P$. phobus gazeli from all other samples of $P$. phobus from Southern Alps at the GOT-2 locus, for instance). The situation was different at the AK-2, G-6-PDH, IDH-2 and 6-PGD loci where, in samples in which no morphologically recognizable sign of hybridization was detected, the two species had no allele in common. The pooled data for these four loci are presented in table 2. These loci can therefore be used as diagnostic at a $100 \%$ level (Ayala, 1983). 
TABLE 2

Pooled number of alleles found in samples from populations without supposed hybrids

\begin{tabular}{c|c|c|c}
\hline \multicolumn{1}{c|}{ Locus } & Allele & $\begin{array}{c}\text { Number of alleles } \\
\text { in } P \text {. apollo }\end{array}$ & $\begin{array}{c}\text { Number of alleles } \\
\text { in } P \text {. phoebus }\end{array}$ \\
\hline AK-2 $\ldots \ldots \ldots \ldots \ldots$ & 100 & 96 & 0 \\
& 110 & 0 & 306 \\
G-6-PDH $\ldots \ldots \ldots \ldots$ & 100 & 96 & 0 \\
& 105 & 0 & 306 \\
IDH-2 $\ldots \ldots \ldots \ldots$ & 100 & 96 & 0 \\
& 105 & 0 & 222 \\
& 115 & 0 & 84 \\
6-PGD $\ldots \ldots \ldots \ldots$ & 95 & 0 & 306 \\
& 100 & 96 & 0 \\
\hline
\end{tabular}

Among the putative hybrids, the two individuals from the Boréon area were heterozygous at all four diagnostic loci ( $\mathrm{n}^{\circ} 1$ and 2 , table 3 ), while the one butterfly from the Galibier region, identified in the field as being a probable hybrid, was heterozygous at two loci (AK-2, IDH-2) but homozygous for the "phoebus " alleles at the two other loci (G-6-PDH, 6-PGD) ( $\mathrm{n}^{\circ} 3$, table 3). A second individual was found in the same population that was heterozygous at the AK-2 locus and homozygous for the " apollo "-allele at the three other discriminating loci $\left(\mathrm{n}^{\circ} 4\right.$, table 3$)$. This finding was a surprise, since this individual had morphological characteristics of a "pure » apollo.

TABLE 3

Genotypes of four supposed hybrids

\begin{tabular}{c|c|c|c|c|c}
\hline \hline $\mathbf{N}^{\mathrm{N}}$ & Origin & $\begin{array}{c}\text { AK-2 } \\
\text { genotype }\end{array}$ & $\begin{array}{c}\text { G-6-PDH } \\
\text { genotype }\end{array}$ & $\begin{array}{c}\text { IDH-2 } \\
\text { genotype }\end{array}$ & $\begin{array}{c}\text { 6-PGD } \\
\text { genotype }\end{array}$ \\
\hline 1 & Boréon $\ldots \ldots \ldots \ldots \ldots \ldots \ldots \ldots$ & $100 / 110$ & $100 / 105$ & $100 / 105$ & $95 / 100$ \\
2 & Boréon $\ldots \ldots \ldots \ldots \ldots \ldots \ldots \ldots$ & $100 / 110$ & $100 / 105$ & $100 / 105$ & $95 / 100$ \\
3 & Galibier $\ldots \ldots \ldots \ldots \ldots \ldots \ldots \ldots$ & $100 / 110$ & $105 / 105$ & $100 / 115$ & $95 / 95$ \\
4 & Galibier $\ldots \ldots \ldots \ldots \ldots \ldots \ldots$ & $100 / 110$ & $100 / 100$ & $100 / 100$ & $100 / 100$ \\
\hline \hline
\end{tabular}

\section{Discussion}

The data presented here show that it is possible to discriminate $P$. apollo and $P$. phobus on the basis of enzyme electrophoretic analysis. The genetic similarity coefficient, I (NEI, 1975, modified according to HILLIS, 1984) of both species, is 0.77 , which is of the same degree as observed in Pierid butterflies (Geiger \& Scholl, 1985) between markedly distinct species. The four diagnostic loci can thus be used to detect potential hybrids. Electrophoretic data, therefore, may be considered as unambiguous indicators of hybrid butterflies, while morphological characters allowed only strong presumptions. 
It is possible to determine, at least partially, the parentage of the hybrids. Butterflies $\mathrm{n}^{\circ} 1$ and 2 , heterozygous at the four diagnostic loci, are most likely $F 1$ hybrids. On the contrary, individual $\mathrm{n}^{\circ} 3$ was not a $F 1$ but was derived from a backcross with a phobus parent; its morphology is also on the "phobus " side, although conspicuously "hybrid». Butterfly $n^{\circ} 4$, with its "phobus" allele in a genetically and morphologically "apollo" context, may be any generation but results most probably from successive backcrosses with apollo parents.

Electrophoresis therefore affords much more precise indications about the fedtures of hybridization than morphology. This latter is however still useful, especially if both sets of data are combined. Similar conclusions were drawn by LAMB \& AvISE (1987) after a study of hybridization in Anurans.

It is important to note that all morphologically recognized female hybrids were sterile and devoid of functional ovarioles, although with a sphragis and therefore mated. Laboratory bred females appear to suffer from the same abnormality as the natural hybrids, while males are normally fertile (DEscimon et al., in preparation). In spite of this sterility, hybrids and backcross progeny occur at least in some natural populations of Parnassius; the backcross progeny result from crosses between $\mathrm{Fl}$ hybrid males and females of either parental species. In the laboratory, second generation backcrosses ( $F I$ male hybrids $\times$ apollo females) have been obtained. They displayed some developmental perturbation, but a significant number of viable, fertile males were obtained. Thus the conditions for an interspecific gene flow are met.

It is difficult to evaluate the taxonomic significance of these findings with respect to the species status of these taxa. Of course, it is possible to evade the problem by assuming that $P$. apollo and $P$. phrobus enter the very heterogenous categories of not totally differentiated species - semispecies of MAYR (1963) or, according to the terminology of BERNARDI (1980), quasispecies or vicespecies - However, in this case, many species would join these categories, since interspecific hybridization is by no means rare in butterflies (Guillaumin \& Descimon, 1976).

In any case, our observations once again demonstrate the dynamic nature of the evolutionary process. The remaining interesting case is whether the observed gene flow among these populations will lead to an incorporation of genes from one species into the other of whether it will be eventually stopped by the development of stronger isolating mechanisms. We do not know how much time such processes might require but our observations at least provide a chance to monitor the evolution in the populations under study. We therefore plan to observe these populations over a long period.

Received December 15, 1986. Accepted December 15, 1987.

\section{Aknowledgements}

We thank Prof. Dr. A. Scholl, University of Bern, for permitting the use of his facilities and his support of this study. The comments and suggestions of Dr. C. WEBB, the University of the South Pacific, Suva, Fiji, considerably helped to improve this paper. 


\section{References}

ANDERSON E., 1949. Introgressive hybridization. 227 p., John Wiley and Sons, New York.

Ayala F.C., 1983. Enzymes as taxonomic characters. In: Oxford G.S., Rollinson D. (ed.), Protein polymorphism : adaptive and taxonomic significance, 3-26, Academic Press, London.

Barton N., Hewitt G.M., 1983. Hybrid zones as barriers to gene flow. In: OxFord G.S., Rollinson D. (ed.), Protein polymorphism: adaptative and taxonomic significance, 341-360, Academic Press, London.

Bernardi G., 1980. Les catégories taxonomiques de la systématique évolutive. In : Bocquet G., Génermont J., Lamotre M. (ed.), Les problèmes de l'espèce dans le règne animal, tome III, 373-425, Jociété zoologique de France, Paris.

Eisner C., 1966. Parnassidae-Typen in der Sammlung J.C. Eisner. Zool. Verh., 81, 1-189.

Geiger H.J., Scholl A., 1985. Systematics and evolution of holarctic Pierinae (Lepidoptera). An enzyme electrophoretic approach. Experientia, 41, 24-29.

Guillaumin M., Descimon H., 1976. Les problèmes de l'espèce chez les Lépidoptères. In : Bocouet C., Genermont J., Lamotte $M$. (ed.), Les problèmes de l'espèce dans le règne animal, tome I, 129-201, Société zoologique de France, Paris.

Hilu. DS D.M., 1984. Misuse and modification of Nei's genetic distance. Syst. Zool., 33, 238-240.

LAMB T., Avise J.C., 1987. Morphological variability in genetically defined categories of anuran hybrids. Evolution, 41, 157-165.

MAYr E., 1963. Animal species and evolution. 797 p., The Belknap Press of the Harvard University, Cambridge, Massachussets.

Napolitano M., Geiger H., Descimon H., 1988. Structure génétique et démographique de quatre populations provençales de Parnassius (Lepidoptera Papilionidae). Génét., Sél., Evol., 20, 51-62.

NefF N.A., Smith G.R., 1979. Multivariate analysis of hybrid fishes. Syst. Zool., 28, 176-196.

NEI M., 1975. Genetic distance between populations. Am. Natur., 106, 283-292.

Oliver C., 1979. Genetic differentiation and hybrid viability within and between some Lepidoptera species. Am. Natur., 114, 681-694.

Powell J.R., 1983. Interspecific cytoplasmic gene flow in the absence of nuclear gene flow: evidence from Drosophila. Proc. Natl. Acad. Sci. USA, 80, 492-495.

Woodruff, 1973. Natural hybridization and hybrid zones. Syst. Zool, 22, 213-218. 